\title{
The Amazon River: A Major Source of Organic Plastic Additives to the Tropical North Atlantic?
}

\author{
Natascha Schmidt, ${ }^{\dagger}$ (i) Vincent Fauvelle, ${ }^{\dagger}$ Anouck Ody, ${ }^{\dagger}$ Javier Castro-Jiménez, ${ }^{\dagger}$ Julien Jouanno, \\ Thomas Changeux, ${ }^{\dagger}$ Thierry Thibaut, ${ }^{\dagger}$ and Richard Sempéré* ${ }^{\dagger} \dagger$ \\ ${ }^{\dagger}$ Aix-Marseille Univ., Toulon Univ., CNRS, IRD, Mediterranean Institute of Oceanography (MIO), Marseille 13288, France \\ ${ }^{\ddagger}$ LEGOS, Université de Toulouse, IRD, CNRS, CNES, UPS, Toulouse 31400, France
}

\section{Supporting Information}

ABSTRACT: The release of emerging organic contaminants is identified among the most critical hazards to the marine environment, and plastic additives have received growing attention due to their worldwide distribution and potential deleterious effects. Here, we report dissolved surface water concentrations of two important families of plastic additives (organophosphate esters (OPEs) and bisphenols) and other related organic compounds (perfluorinated chemicals) measured in the North Atlantic from Cape Verde to the West Indies. We found that OPEs were the most abundant contaminants, reaching remarkably high concentrations in open ocean waters $(1200 \mathrm{~km}$ offshore of the American Coast, at the location of the Amazon river plume during the sampling

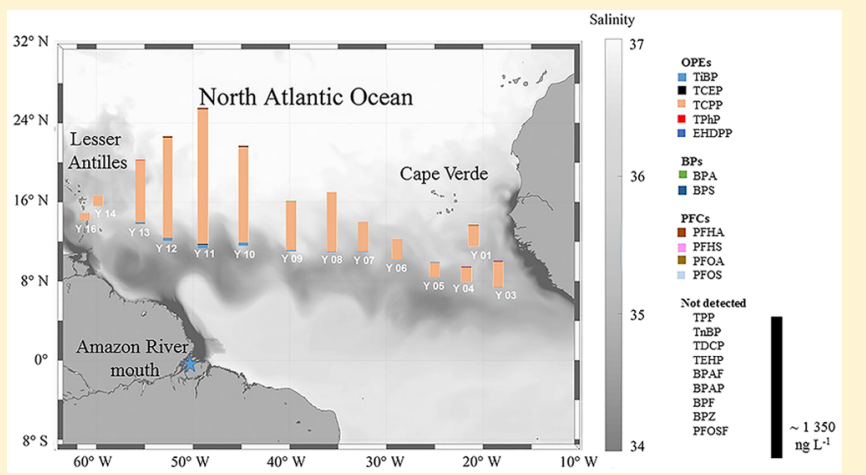
period), with up to $1.3 \mu \mathrm{g} \mathrm{L}{ }^{-1}\left(\Sigma_{9} \mathrm{OPEs}\right)$. A Lagrangian analysis confirmed that these high concentrations of contaminants originated from the Amazon River plume and were transported more than $3000 \mathrm{~km}$ by the North Brazil Current and its retroflection. We thus consider the Amazon River as a major source of organic contaminants of emerging concern to the tropical North Atlantic Ocean and suggest that medium-/long-range contaminant transport occurs, most certainly facilitated by the highly stratified conditions offered by the river plume.

\section{INTRODUCTION}

Over the past few decades, the dramatic increase in plastic and, more generally, chemical production volumes has led to the widespread occurrence of organic contaminants in all water bodies, including marine environments and numerous living organisms. ${ }^{1}$ Organophosphate ester (OPE) flame retardants and plasticizers are among the most common organic plastic additives, representing up to $7 \%$ by mass of global plastic production. ${ }^{2}$ The most important OPE by production volume is tris(2-chloro, 1-methylethyl) phosphate (TCPP). ${ }^{3}$ Although the occurrence of OPEs in indoor and outdoor air, freshwater environments, sediments, and soils is relatively well-documented, ${ }^{4-7}$ there are still many open questions concerning the distribution and fate of OPEs in the marine environment. OPEs have been reported as persistent, bioaccumulative, and toxic. ${ }^{5}$ While most research focuses on Asia (mainly China), ${ }^{8-10}$ and Europe ${ }^{11-13}$ and some focuses on North America, ${ }^{14-16}$ no data for South American rivers, lakes or coastal areas are available to date to the best of our knowledge.

Bisphenols (BPs), known for their endocrine-disrupting properties, which have led to various national and international bans and regulations, are still used in the production of thermal paper, plastic bottles and food can linings, among other items. $^{17,18}$ Bisphenols have been detected in sediment and seawater samples ${ }^{19,20}$ as well as in the atmosphere, where the presence of bisphenol A (BPA) has been linked to plastic burning. ${ }^{21}$ Perfluorinated compounds (PFCs) have water- and oil-resistant properties and therefore are used in outdoor textiles and food packaging as well as in fire-fighting foams. ${ }^{22,23}$ PFCs are very resistant to heat and chemicals, which qualifies them as persistent pollutants in the environment. Perfluorooctanesulfonic acid (PFOS) and PFOS precursors have therefore been listed as persistent organic pollutants (POPs) under the Stockholm Convention. ${ }^{24}$ PFCs have been detected in remote regions, such as the Central Arctic Ocean, ${ }^{25}$ and the most oligotrophic areas of the subtropical Atlantic, Pacific, and Indian oceans ${ }^{26}$ as well as in coastal waters. ${ }^{27}$ The main source of PFCs in the marine environment is river inputs. ${ }^{28}$

To study their waterborne occurrence and possible sources in the tropical North Atlantic Ocean, surface seawater samples were collected in October 2017 at 14 coastal and open ocean stations (Table S1) during the Transatlantic Sargassum expedition (https://doi.org/10.17600/17016900) on the M/ $\mathrm{V}$ Yersin from Cape Verde to Martinique Island (Lesser Antilles) along $6000 \mathrm{~km}$. Seawater samples were analyzed for

Received: March 26, 2019

Revised: June 4, 2019

Accepted: June 4, 2019

Published: June 4, 2019 

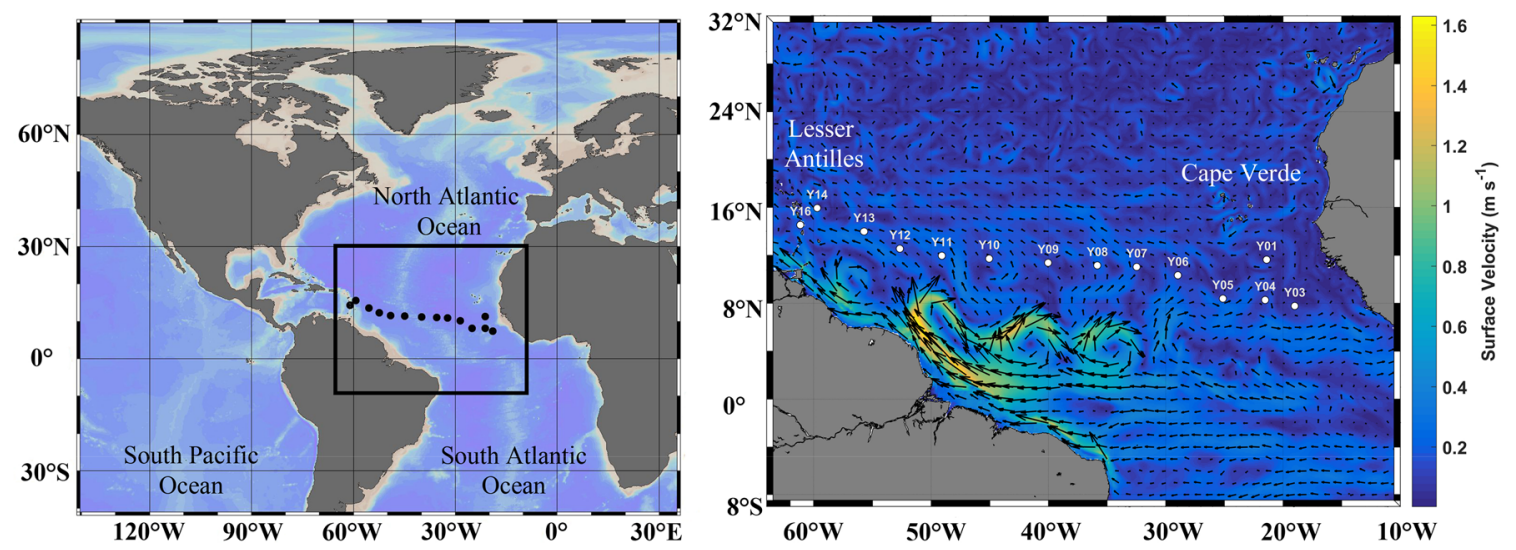

Figure 1. Map showing the position of the sampling area in the North Atlantic Ocean as well as a zoom showing the individual sampling stations and the mean water surface velocity (in $\mathrm{m} \mathrm{s}^{-1}$ ) observed during the sampling period (October 2017).

20 organic contaminants of emerging concern, including OPEs, BPs, and PFCs, by applying a multicontaminant extraction protocol. A Lagrangian analysis was used to investigate the origin of the sampled surface waters.

\section{METHODS}

Contaminant Analysis. One-liter seawater samples were collected in duplicate at 14 sampling stations (Table S1, Figure 1 ), amounting to a total of 28 samples. They were collected using an inox collector, poured into corresponding precombusted $\left(450{ }^{\circ} \mathrm{C}, 6 \mathrm{~h}\right)$ glass bottles, GF/F-filtered $(0.7 \mu \mathrm{m})$, and stored in a refrigerator for a maximum of $72 \mathrm{~h}$ before sample processing. Samples were analyzed for nine organophosphate esters (tripropyl phosphate (TPP), triisobutyl phosphate (TiBP), tri- $n$-butyl phosphate (TnBP), tris(2-chloroethyl) phosphate (TCEP), tris(2-chloro-1-methylethyl) phosphate (TCPP), tris(2-chloro-, 1-chloromethylethyl) phosphate (TDCP), triphenyl phosphate (TPhP), 2-ethylhexyldiphenyl phosphate (EHDPP), and tris(2-ethylhexyl) phosphate (TEHP)), five perfluorinated compounds (perfluorohexanoic acid (PFHA), perfluorohexanesulfonic acid (PFHS), perfluorooctanoic acid (PFOA), perfluorooctanesulfonic acid (PFOS), and perfluorooctane sulfonyl fluoride (PFOSF)), and six bisphenols (bisphenol A (BPA), bisphenol AF (BPAF), bisphenol AP (BPAP), bisphenol F (BPF), bisphenol $S$ (BPS), and bisphenol Z (BPZ)). To do so, organic contaminants were extracted from batches of two replicates from three stations on-board using solid phase extraction (SPE). ${ }^{29}$ Briefly, glass cartridges containing $250 \mathrm{mg}$ of HLB Oasis sorbent (Waters, Milford, MA) were mounted on a manifold (Supelco Visiprep) and rinsed three times sequentially with $10 \mathrm{~mL}$ of ethyl acetate and $10 \mathrm{~mL}$ of methanol. Next, $10 \mathrm{~mL}$ of ultrapure water were passed through the cartridges. The seawater samples were spiked with surrogate standards (100 ng sample ${ }^{-1}$ of $\mathrm{D}_{27}$-TBP, $\mathrm{D}_{18}$-TCPP, $\mathrm{D}_{15^{-}}$ TDCP, and $\left.\mathrm{D}_{15}-\mathrm{TPhP}\right)$, vigorously shaken and passed through the cartridges using polytetrafluoroethylene (PTFE) liners, which were previously cleaned thoroughly with methanol.

Afterward, $10 \mathrm{~mL}$ of ultrapure water was again passed through the cartridges. The cartridges were then vacuum-dried for approximately $1 \mathrm{~h}$, wrapped in burnt aluminum foil, and stored in the freezer $\left(-25{ }^{\circ} \mathrm{C}\right)$. Upon arrival in the ISO 6 laboratory equipped for trace-clean analysis of organic compounds, a sequential elution was performed as follows: 5 $\mathrm{mL}$ of hexane followed by $5 \mathrm{~mL}$ of hexane/dichloromethane
$50: 50(\mathrm{v} / \mathrm{v})(\mathrm{F} 1)$ and $5 \mathrm{~mL}$ of ethyl acetate followed by $5 \mathrm{~mL}$ of methanol (F2). The two fractions were then evaporated with pure $\mathrm{N}_{2}$ gas until a final volume of approximately $50 \mu \mathrm{L}$ was left (F1) or until dryness (F2), in which case the extract was then reconstituted using $990 \mu \mathrm{L}$ of methanol. Internal standards were added as follows: $100 \mathrm{ng}$ sample ${ }^{-1}$ of $\mathrm{D}_{21}-\mathrm{TPrP}$, $\mathrm{D}_{12}$-TCEP and $\mathrm{D}_{7}$-malathion ( $\left.\mathrm{F} 1\right)$, and $20 \mathrm{ng}$ sample ${ }^{-1}$ of BPA-D ${ }_{16}$, PFHA- ${ }^{13} \mathrm{C}_{5}$, PFBS $-{ }^{13} \mathrm{C}_{3}$, PFHS- $-{ }^{13} \mathrm{C}_{3}$, and PFOS $-{ }^{13} \mathrm{C}_{8}$ (F2). OPEs were quantified by GC/MS (Agilent Technology 7820A-5977E) in the splitless selected ion monitoring (SIM) mode. The separation was achieved using a $30 \mathrm{~m} \times 0.25 \mathrm{~mm}$ i.d. $\times 0.25 \mu \mathrm{m}$ HP-5MS capillary column (Agilent J\&W). PFCs and BPs were quantified using LC-QTOF (Agilent 1290 Infinity LC system coupled with Agilent 6530 Accurate-Mass Q-TOF, Agilent Technologies, Les Ulis, France). Separation was achieved using an Agilent Zorbax Eclipse XDB reversedphase column $(50 \mathrm{~mm} \times 2.1 \mathrm{~mm}, 1.8 \mu \mathrm{m})$, with the temperature set at $30{ }^{\circ} \mathrm{C}$. GC/MS and LC-QTOF method details are given in the Supporting Information (Text S1 and Tables S2 and S3). CAS numbers of each compound are given in Table S4.

Quality Assurance/Quality Control (QA/QC). Strict QA/QC measurements were implemented. Extraction, transport, and laboratory blanks were made and analyzed concurrently with the samples to detect possible contaminations. Blank levels and compound concentrations of samples are presented in Table S5. No contamination was found, except in the case of TCPP, where mean blank levels $(n=5)$ of $\sim 16 \mathrm{ng}$ were detected, and for some PFCs and BPs, where trace levels were detected in the blanks $(\mathrm{PFHA}<\mathrm{LOQ}$, PFOA n.d. - < LOQ, PFOS n.d. - < LOQ BPA n.d. - 1.0 ng L ${ }^{-1}$, and BPS n.d. - <LOQ). The transport blank showed similar blank levels as field blanks, excluding sample contamination during transport and storing. The results presented here are blankcorrected. Limits of quantification (LOQs) ranged from 0.03 to $8 \mathrm{ng} \mathrm{L}{ }^{-1}$ (all LOQs are given in Table S4). If compounds were detected at concentrations $<$ LOQ, they were considered as zero (i.e., not detected) for the calculation of detection frequencies and sums. Mean surrogate recovery rates were as follows: $\mathrm{D}_{27}$-TBP $74 \%, \mathrm{D}_{18}$-TCPP $70 \%, \mathrm{D}_{15}$-TDCP $76 \%$, and $\mathrm{D}_{15}-\mathrm{TPhP} 71 \%$ (see Table S6 for all recovery rates). The results presented here are not recovery corrected. The variability between duplicate samples ranged between 6 and $27 \%$. 

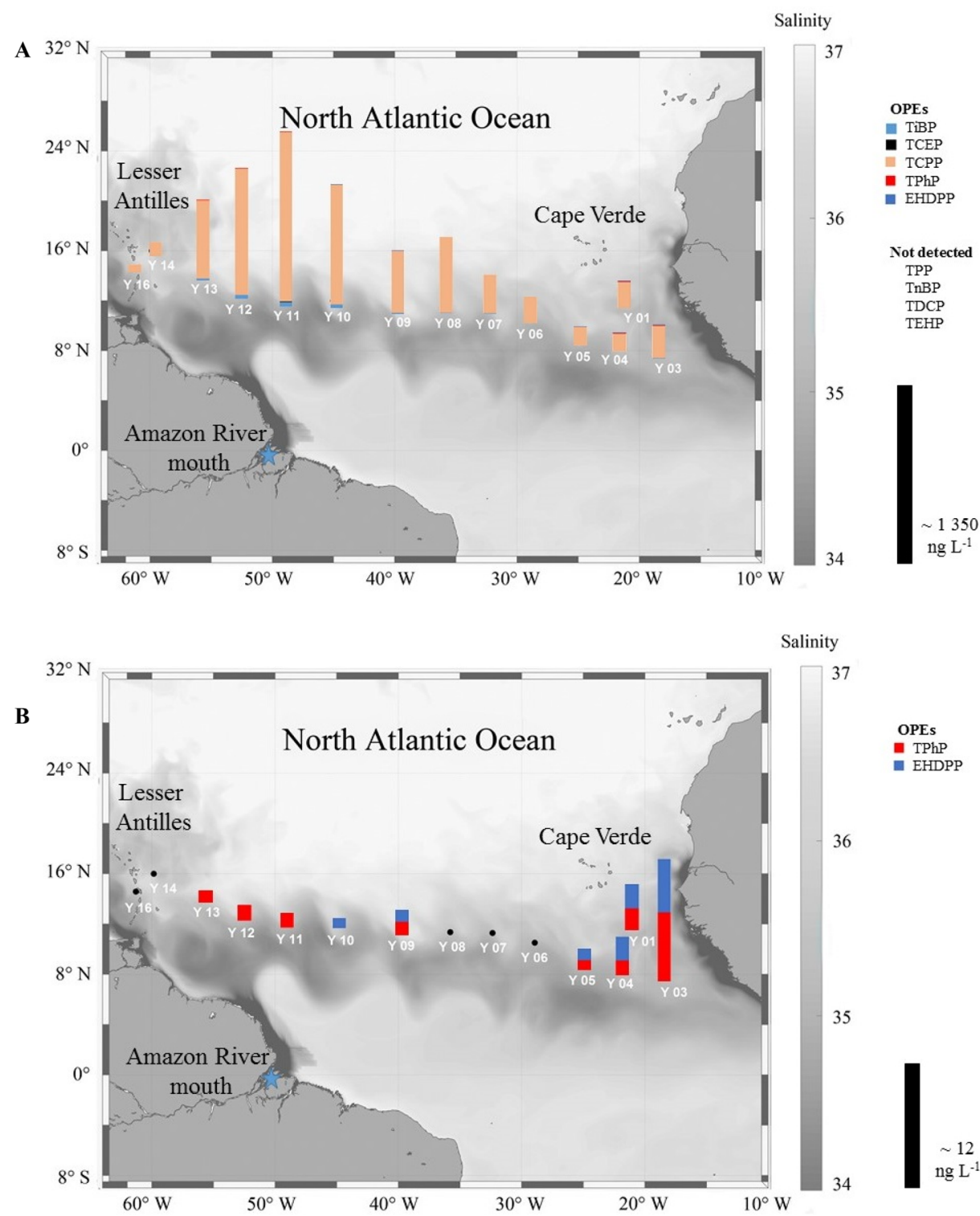

Figure 2. Concentrations (in $\mathrm{n} \mathrm{L}^{-1}$ ) of the individual OPEs (A) and the two compounds TPhP and EHDPP (B) which do not completely follow the same dynamics as $\Sigma$ OPEs. Monthly average salinity distribution in the surface waters of the tropical North Atlantic in October 2017 is indicated as well as the Amazon River mouth (blue star). Lower salinity areas are colored in dark gray. In the west, areas showing lower salinity are mainly influenced by freshwater inputs from the Amazon River, while in the east Intertropical Convergence Zone (ITCZ) rainfall is presumably at the origin of lower salinity waters.

Solvents and Reagents. Solvents were purchased from Promochem (hexane, ethyl acetate and dichloromethane, Picograde, LGC standard) and Biosolve (methanol, ULCMS grade). Isotope-labeled PFCs were purchased from Wellington Laboratories (Canada) and labeled OPEs from $\mathrm{C} / \mathrm{D} / \mathrm{N}$ Isotopes Inc. (Canada) $\left(\mathrm{D}_{27^{-}} \mathrm{TBP}, \mathrm{D}_{15^{-}} \mathrm{TPhP}, \mathrm{D}_{21^{-}}\right.$ $\mathrm{TPrP}$, and $\mathrm{D}_{7}$-malathion) and from Cambridge Isotope Laboratories, Inc. (USA) $\left(\mathrm{D}_{18^{-}}\right.$TCPP, $\mathrm{D}_{15^{-}}$TDCP and $\mathrm{D}_{12^{-}}$ TCEP). Isotope-labeled bisphenols were obtained from AccuStandard (USA).

Salinity and Velocity Maps. Daily surface salinity and velocity fields at $1 / 12^{\circ}(\sim 8 \mathrm{~km})$ were computed by the Operational Mercator global ocean analysis and forecast system PSY4 V3R1 from MERCATOR-OCEAN. ${ }^{30}$ This system used version 3.1 of the NEMO ocean model, which solves the three-dimensional primitive hydrodynamic equations in spherical coordinates discretized on a C-grid and 50 vertical levels, under the hypothesis of boussinesq, hydrostatics, and incompressibility. ${ }^{31}$ This model is forced by realistic surface fluxes from ECMWF and jointly assimilates altimeter data, vertical in situ temperature and salinity profiles, and satellite sea surface temperature. Data were downloaded for the surface layer $(<1 \mathrm{~m}$ depth) of the whole North Atlantic Ocean from the Marine Copernicus Portal (GLOBAL_ANALYSIS_FORECAST_PHY_001_024; http://marine. copernicus.eu/services-portfolio/access-to-products/).

Backward Trajectories. Backward Lagrangian particle trajectories were computed using the Lagrangian transport model Ichthyop, ${ }^{32}$ which simulates horizontal and vertical advection and dispersion. In our study, we considered our particles as passive surface tracers and only used horizontal advection in the movement equation. The Ichthyop model was run using the MERCATOR-OCEAN daily surface velocity fields at $1 / 12^{\circ}$ described above. These fields were interpolated 


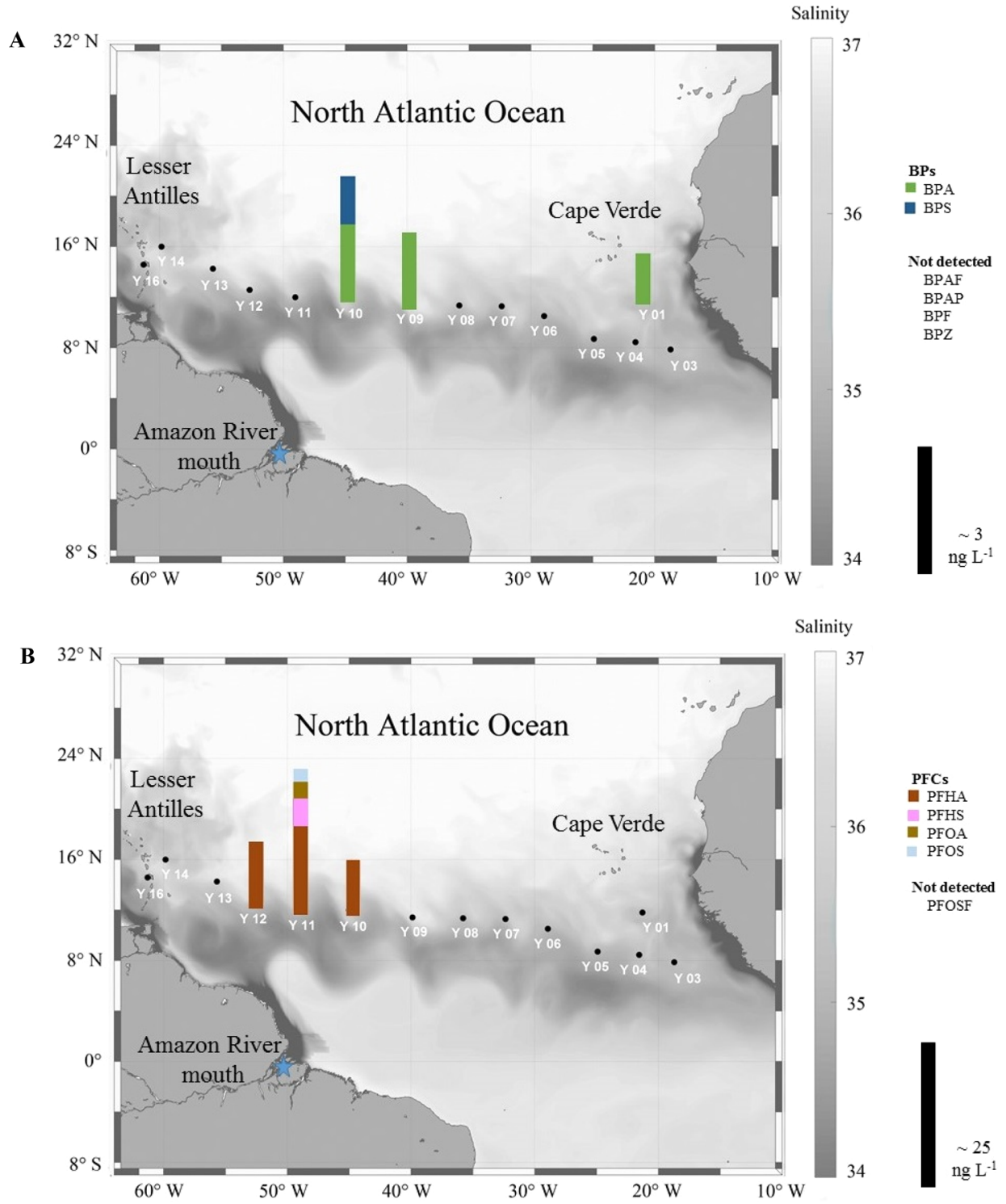

Figure 3. Concentrations (in ng $\mathrm{L}^{-1}$ ) of the individual BPs (A) and PFCs (B) detected at sampling stations Y01-Y16. Monthly average salinity distribution in the surface waters of the tropical North Atlantic in October 2017 is indicated as well as the Amazon River mouth (blue star).

in space and time using a fourth order Runge-Kutta integration scheme with a constant time step of $1800 \mathrm{~s}$ that respected the Courant-Friedrichs-Lewy (CFL) criterion on the entire domain. Each sampled surface water mass was modeled by a circular patch with a radius of $10 \mathrm{~km}$ and seeded at the surface with 400 randomly released particles (i.e., approximately 1.3 particles $\mathrm{km}^{-2}$ ) at the station times and geographic coordinates. Horizontal particle advection was carried out for 180 days with an output time step of $12 \mathrm{~h}$. At the end of each simulation, the percentage of seeded particles that passed in the Amazon Estuary area was computed, as well as the number of days between the day that they left the Amazon estuary area and the sampling day of the water masses. The Amazon Estuary area is hereby represented by a box, including longitude between $-52^{\circ} \mathrm{E}$ and $-46^{\circ} \mathrm{E}$ and latitude between $-2^{\circ} \mathrm{N}$ and $3^{\circ} \mathrm{N}$. Simulation was not run for station Y16 because of its high proximity to the coast $(4 \mathrm{~km}$; lower than the current model resolution).

The choice of a particle patch radius of $10 \mathrm{~km}$ for the backward trajectory simulations was motivated by two arguments: the radius needed (i) to be small enough to be representative of the sampled water mass and (ii) to be large enough to include at least two meshes of the velocity field in diameter to take into account possible shifts between modeled and actual velocity fields. Comparison between daily salinity maps and seeded patch areas shows that a $10-\mathrm{km}$ patch size allows for representation of a water mass with a salinity variability lower than \pm 0.2 , in comparison with the overall salinity varying between $\sim 34$ inside the Amazon River plume to 37 in the surrounding seawater (Figure S1). In addition, sensitivity tests for radii from 5 to $25 \mathrm{~km}$ and densities from 0.5 to 2.5 particles $\mathrm{km}^{-2}$ were performed to test the robustness of our results (Table S7). The upper limit of $25 \mathrm{~km}$ was chosen because higher radii showed too much salinity variability inside patch areas to be consistent with the sampled water mass. These tests showed that the sensitivity of our results to the seeded patch radius and the particle density was very low, with a maximum difference in particle percentage that passed through the Amazon estuary area (Amazon box) lower than $10 \%$, except at stations Y04 (40\%) and Y14 (26\%). 


\section{RESULTS AND DISCUSSION}

OPEs were detected in all samples, while BPs and PFCs were each only detected in 3 of 14 samples. From the nine OPEs analyzed, TPP, TnBP, TEHP, and TDCP were not detected, while TCEP was found only at trace levels $<2 \mathrm{ng} \mathrm{L}^{-1}$ in $36 \%$ of samples. TCPP was detected in all samples, followed by TiBP and $\mathrm{TPhP}$ (93 and 57\% detection frequency, respectively, Figure S2). Concerning bisphenols, BPA was detected at stations Y01, Y09, and Y10, and BPS was found at station Y10, while the remaining four bisphenols were not detected in any samples. Of the five PFCs studied, only PFOSF was not detected at all. PFHS, PFOA, and PFOS were found at one sampling station (Y11), while PFHA was detected in $21 \%$ of samples.

OPEs were the most abundant compound class with a relative abundance of $98-100 \%$, followed by PFCs $(0-1.9 \%)$ and, finally, bisphenols (0-0.6\%). The highest amounts of $\Sigma_{9}$ OPEs were measured at stations Y11, Y12, and Y10 (1340, 1000 , and $955 \mathrm{ng} \mathrm{L}^{-1}$, respectively), hence, in offshore waters (Figure 2A). In contrast, the two stations showing the lowest $\Sigma_{9}$ OPEs concentrations (Y16 and Y14, 74 and $106 \mathrm{ng} \mathrm{L}^{-1}$, respectively) are in the most western coastal area. TCPP was hereby the most abundant OPE, with concentrations ranging from 74 (station Y16) to $\sim 1300 \mathrm{ng} \mathrm{L}^{-1}$ (station Y11) and a relative abundance ranging from 92 to $100 \%$. TiBP concentrations ranged from $<1$ (station $\mathrm{Y} 16$ ) to $38 \mathrm{ng} \mathrm{L}^{-1}$ (station Y11). In contrast, the maximum TPhP and EHDPP concentrations were measured at station $\mathrm{Y} 03\left(7 \mathrm{ng} \mathrm{L}{ }^{-1}\right.$ and 5 ng $\mathrm{L}^{-1}$, respectively), closer to the NW African coast (Figure 2B). These two compounds exhibit thus a different distribution pattern than $\Sigma_{9}$ OPEs, possibly due to different sources and/or degradation rates. TPhP and EHDPP are used in hydraulic fluids, ${ }^{3}$ among others, and the fact that they exhibited highest concentrations at stations closest to the NW African coast could possibly be due to the high fishing activities in this area and other maritime traffic. This is in agreement with another study ${ }^{33}$ reporting that EHDPP concentrations seem to derive mainly from local sources (airports, harbors, and naval bases, urbanized and industrial areas) instead of from waterborne transport.

Station Y11, which was characterized by the highest $\Sigma_{9} \mathrm{OPEs}$ concentrations, is the station closest to the Amazon River estuary, with a distance of approximately $1200 \mathrm{~km}$. Despite the large distance involved, diluted water from the Amazon River has already been found in the Caribbean Sea and has been shown to influence the tropical Atlantic Ocean more than 3500 $\mathrm{km}$ away from the river mouth. ${ }^{34}$ The freshwater is hereby transported by the North Brazil Current (NBC) and the North Equatorial Counter Current (NECC). Our results indicate, that medium-/long-range transport of OPEs via the water phase is occurring, further challenging the consideration of OPEs as being environmentally friendly alternatives for brominated flame retardants. This observation seems to be especially true for chlorinated OPEs, such as TCPP, since they are more persistent than nonchlorinated OPEs. ${ }^{35}$ Furthermore, it has been suggested that chlorinated OPEs have a longer characteristic travel distance in water than in air, ${ }^{33}$ supporting the hypothesis of water-borne medium-/long-range transport. This could be a particular reason for concern, since especially chlorinated OPEs are considered to have negative impacts on human health and the environment. ${ }^{3}$
Generally, OPE levels in rivers and their estuaries can be very variable and can depend on the season. ${ }^{36}$ TCPP concentrations ranging from 4.6 to $921 \mathrm{ng} \mathrm{L}^{-1}$ were measured in rivers in northern China, ${ }^{37}$ concentrations of $126 \pm 14 \mathrm{ng}$ $\mathrm{L}^{-1}$ were found in the Elbe River in Germany, ${ }^{38}$ and concentrations of $1.1-4.4 \mu \mathrm{g} \mathrm{L}^{-1}$ were measured in streams in Toronto, Canada. ${ }^{39}$ These ranges are comparable with our results (74-1300 $\mathrm{ng} \mathrm{L}^{-1}$ of TCPP).

Bisphenols and perfluorinated compounds were present at lower concentrations than OPEs (Table S5). BPA concentrations ranged between $1.2 \mathrm{ng} \mathrm{L}^{-1}$ (station Y01) and $1.8 \mathrm{ng}$ $\mathrm{L}^{-1}$ (Y09 and Y10), while BPS was found at $1.1 \mathrm{ng} \mathrm{L}^{-1}$ (Y10) (Figure 3A). While BPS is used as a substitute for BPA in certain products (e.g., in thermal paper or polycarbonate plastics), BPA is still dominating these sectors, ${ }^{18,40}$ probably explaining why BPA was more abundant in our samples than BPS. The finding that bisphenols were only found at concentrations lower than $2 \mathrm{ng} \mathrm{L^{-1 }}$ or not detected at all could be due to rapid degradation rates. According to the simulation of the backward trajectories (see below), the surface waters needed at least two months after leaving the Amazon River estuary before they reached the sampling stations. It was observed that complete biodegradation of BPA in river water was achieved within a few days, even at high initial concentrations (up to $5500 \mu \mathrm{g} \mathrm{L}^{-1}$ ). ${ }^{41}$ The presence of bisphenols at stations Y09 and Y10, and especially at Y01, is thus probably not necessarily linked to the Amazon River, but could for example originate from ships that recently passed through or near the sampling area. Similar to the OPE results, Y11 was the station that exhibited the highest $\Sigma_{5} \mathrm{PFCs}$ concentration (26 $\mathrm{ng} \mathrm{L^{-1 }}$ ) and, in particular, the highest PFHA concentration $\left(16 \mathrm{ng} \mathrm{L}{ }^{-1}\right)$, followed in this case by the

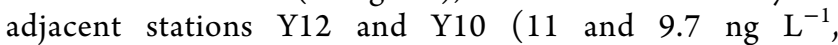
respectively). At station Y11, PFHS was found at $4.4 \mathrm{ng} \mathrm{L}^{-1}$, PFOA at $2.9 \mathrm{ng} \mathrm{L}^{-1}$, and PFOS at $2.3 \mathrm{ng} \mathrm{L}^{-1}$ (Figure $3 \mathrm{~B}$ ). This PFOS concentration is quite high, especially for open-ocean waters. As a reference, it clearly exceeded the European Environmental Quality Standard (EQS) for PFOS (0.13 ng $\mathrm{L}^{-1}$ for marine waters, directive 2013/39/EU). PFHA concentrations in seawater generally tend to be very low, with $0.02-0.19 \mathrm{ng} \mathrm{L}^{-1}$ of PFHA measured in Western Mediterranean waters ${ }^{23}$ and $<0.003-0.12 \mathrm{ng} \mathrm{L}^{-1}$ detected in seawater samples from Northern Europe, the Atlantic Ocean, and the Southern Ocean. ${ }^{22}$ A study analyzing PFHA in surface seawater samples close (at a distance of $140-370 \mathrm{~km}$ ) to our sampling stations Y16, Y14, and Y05 found concentrations between n.d. and $0.0187 \mathrm{ng} \mathrm{L}^{-1}$, values that were comparable with ours (n.d. or <LOQ) at the three stations mentioned above. ${ }^{26}$ In contrast, PFHA concentrations in rivers have been found to vary between 0.50 and $5.3 \mathrm{ng} \mathrm{L}^{-1}$ (Elbe and Weser Rivers in Germany) ${ }^{42}$ and between $<0.10$ and $38 \mathrm{ng} \mathrm{L}^{-1}$ (data from 29 Chinese rivers) ${ }^{43}$ or reach peak concentrations of up to $16000 \mathrm{ng} \mathrm{L}{ }^{-1}$ downstream of a PFC production facility (Samondogawa River in Japan). ${ }^{44}$ Our PFHA concentrations at stations Y11, Y12, and Y10 $\left(16,11\right.$, and $9.7 \mathrm{ng} \mathrm{L}^{-1}$, respectively) thus seem quite high for seawater samples and indicate once again a riverine source, i.e., the Amazon River.

A recent study proposed fire-fighting foams used at offshore oil and gas platforms to be a potentially important PFC source to the marine environment. ${ }^{45}$ Important oil and gas drilling close to our study area mainly occurs in the Campos and Santos basins off the coasts of Rio de Janeiro and Sao Paulo, Brazil. Given the direction of the oceanic currents there (from 
a

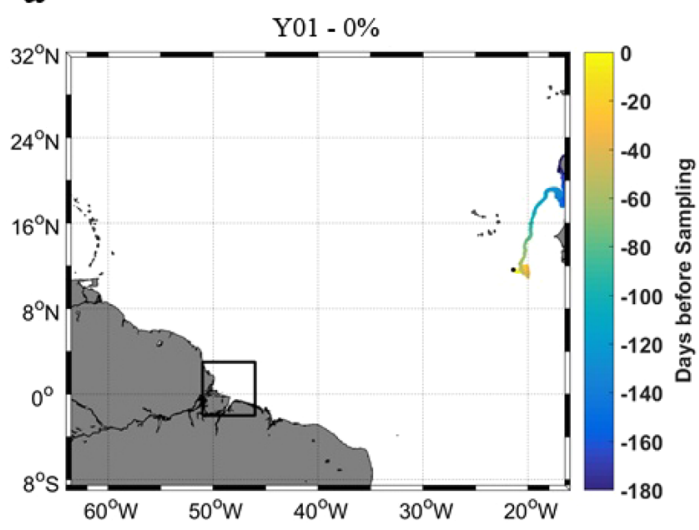

c

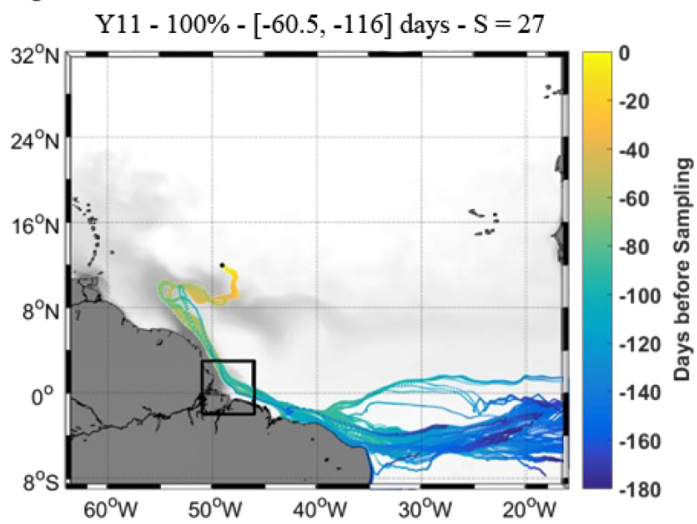

b

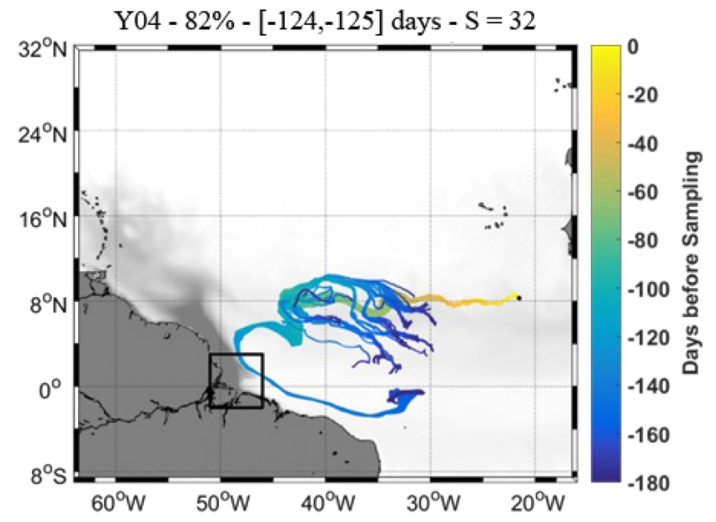

d

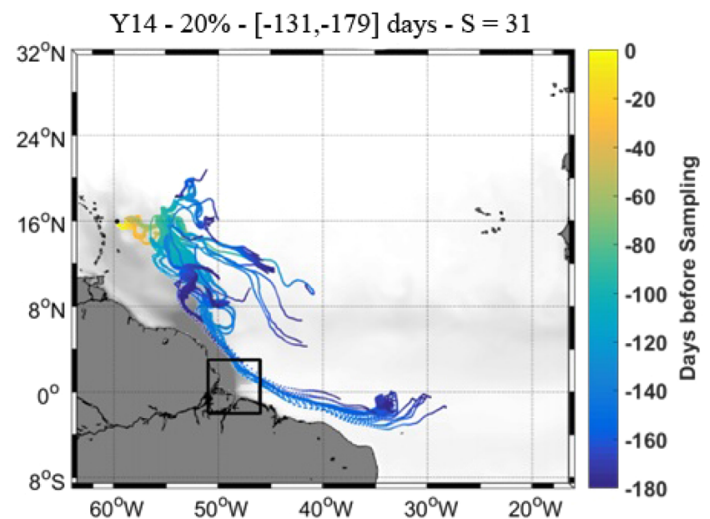

Figure 4. Water mass backward trajectories for the stations Y01 (a), Y04 (b), Y11 (c), and Y14 (d). Each map has a caption indicating the station ID, the date, the percentage of water masses that were in the black box (indicating the Amazon Estuary), and the number of days that passed between the sampling of the water masses and their journey in the area of the black box (in brackets). The minimum salinity $(S)$ reached by particles during their journey in the black box is indicated as well as the river plume (with a dark to light gray scale; $S=27-37$ ).

north to south; not toward our sampling stations), these offshore platforms do not seem to be a plausible explanation for the high PFC concentrations detected at stations Y10-Y12. However, multiple studies ${ }^{46-48}$ have investigated the magnitude of oil and gas extractions in the Amazon basin and the farreaching environmental impacts. These inland oil and gas extraction activities and the associated use of fire-fighting foams could thus be a possible explanation of the PFC concentrations observed. Another potential source of PFCs, OPEs, and BPs in the Amazon basin could be the city of Manaus, which houses an important industry producing chemicals and electronic equipment, among others. Furthermore, more than two million people live in Manaus, but less than $20 \%$ of households are connected to the sewage system. ${ }^{49}$

Low surface salinity (between 33 and 35; Table S1 and Figure S3) was measured at all stations. In the west, this freshening is thought to be primarily due to transport of freshwater from the Amazon, while to the east it mainly emanates from Intertropical Convergence Zone (ITCZ) rainfall. $^{50}$ These trends were also observed for the chlorophyll a spatial concentration distribution, represented by $\mathrm{Kd} 490$ (Figure S4). To confirm the origin of the sampled surface waters, a Lagrangian analysis was performed. Simulations using MERCATOR daily surface velocity fields indicated that 98$100 \%$ of the surface waters encountered at stations Y06-Y08 and Y10-Y13 passed near or originated from the Amazon River mouth. While the model cannot distinguish whether the surface waters passed by the Amazon River estuary or originated from the river itself, the term "originated from" will be used hereafter in accordance with our hypothesis. According to the simulation, the farthest east where an influence of the Amazon can be observed is at station Y04, where $82 \%$ of surface waters originated from the far east corner of the black box enclosing the river estuary (Figure 4; backward trajectories for all stations are provided in Figure S5). These results indicate that the influence of the Amazon River is reaching far into the North Atlantic since even water masses and contaminant concentrations from sampling stations close to the African continent were partially linked to the Amazon River. Hereby, the surface waters of station Y04 $\left(8^{\circ} \mathrm{N}\right.$, $21^{\circ} \mathrm{W}$ ) had a calculated travel time of $\sim 125$ days, which is in good agreement with the results obtained by Coles et al., who found that drifters released in the Amazon River estuary reached this zone after approximately $120-150$ days. ${ }^{51}$ Stations with high contaminant levels seem generally characterized by (i) a high percentage of surface waters that originated in the Amazon River plume, (ii) a short travel time, and/or a short travel distance and (iii) an origin close to the river mouth where contamination is probably highest. However, we point out that the Lagrangian approach used to simulate the backward trajectories does not take vertical mixing into account, which can complexify (or partly explain some discrepancies in) the relationship between contaminant concentration and percentage, origin, and travel time of 
surface water masses. Similarly, for station Y09 the simulation suggests that $0 \%$ of surface waters originated from the Amazon River mouth, even though the total contaminant level is relatively high $\left(\sim 480 \mathrm{ng} \mathrm{L}^{-1}\right)$.

Another explanation for the contamination pattern observed could be that not the Amazon River itself is the source, but that the contaminants originate from coastal areas near the river mouth. In this case, a potential source could, for example, be the metropolis of Belém, including its two airports and the naval base. Furthermore, a phenomenon that could explain the high contaminant concentrations measured in this study could be the transfer of contaminants from the atmosphere to surface waters of the tropical North Atlantic via atmospheric deposition. A recent study (based on cruise measurements) estimated that between 0.2 and $2.5 \mathrm{Kt}^{-1}$ of OPEs $\left(\sum_{14}\right.$ OPEs) associated with atmospheric dry deposition fluxes could be loaded to the entire Atlantic Ocean (surface of $8.2 \times 10^{13}$ $\left.\mathrm{m}^{2}\right){ }^{52}$ To investigate this possibility, NOAA's HYSPLIT model $^{53,54}$ was used to simulate air mass backward trajectories. However, while a background atmospheric deposition of OPEs cannot be excluded, the simulation results suggest that potential atmospheric inputs were not related to the Amazon area. Air masses from most stations originated from a northeastern direction (Figure S6), close to the NW African and European coasts, and could thus not convincingly explain why highest contaminant concentrations were measured at stations far away from the African and European coasts.

The Amazon drainage basin represents approximately $7500000 \mathrm{~km}^{2}$, and each second it discharges an average of $209000 \mathrm{~m}^{3}$ of freshwater into the Atlantic Ocean, representing up to $20 \%$ of the freshwater input to the global ocean. ${ }^{55}$ It also exports considerable amounts of DOC and dissolved organic matter (DOM). ${ }^{55,56}$ Furthermore, recent research suggests that the Amazon River is a significant source of plastic pollution, with an estimated input into the Atlantic Ocean of 32000$64000 \mathrm{t}$ per year. ${ }^{57}$ However, little is known about the presence of organic contaminants of emerging concern in the watershed, such as OPEs, PFCs, and bisphenols, which are common plastic additives. The high discharge rate of the river and the high contaminant levels observed in our study strongly suggest that the Amazon River could be a major source of contaminants to the Atlantic Ocean, as well. The surface water backward trajectory simulations further strengthen this hypothesis. Analyzing samples originating from the river itself and monitoring contaminant concentrations during wet and dry seasons will be crucial tasks for the future and will be necessary to fully understand the extent of organic plastic additive occurrence in the Amazon River and their transport to the Atlantic Ocean.

Attention must be focused on the potential effects for freshwater and marine ecosystems but should also be given to the consequences for local communities that use river water for agriculture or household activities. New evidence suggests that long-term exposure to high OPE concentrations could significantly affect marine organisms and human health by influencing the immune system or disturbing cell growth, among others. ${ }^{58,59}$ While these effects need to be studied further, findings such as those presented here help to identify geographical zones of scientific interest and to note the current magnitude of environmental pollution that calls for changes in uses and practices at the scale of the Amazon watershed. The importance of the situation is highlighted when we consider that future climate scenarios predict an increase in the discharge of the Amazon River ${ }^{60}$ and that plastic litter in the Amazon watershed is expected to double between 2010 and 2025 . $^{61}$

\section{ASSOCIATED CONTENT}

\section{S Supporting Information}

The Supporting Information is available free of charge on the ACS Publications website at DOI: 10.1021/acs.est.9b01585.

GC/MS and LC-HRMS method details; salinity maps of seeded particle patches; detection frequencies of organic compounds; daily surface salinity maps; maps of sampling area and Kd490 distribution; water mass backward trajectories; air mass backward trajectories; GPS positions and measured salinity; quantification ions; LOQs; contaminant concentrations in blanks and samples; surrogate recoveries; sensitivity test results for water mass backward trajectories (PDF)

\section{AUTHOR INFORMATION}

\section{Corresponding Author}

*E-mail: richard.sempere@mio.osupytheas.fr.

ORCID

Natascha Schmidt: 0000-0002-6194-3999

Javier Castro-Jiménez: 0000-0001-8456-3932

Notes

The authors declare no competing financial interest.

\section{ACKNOWLEDGMENTS}

We deeply thank the crew and captain of the M/V Yersin as well as HSH Prince Albert II of Monaco and Monaco Explorations. Thanks to Laurent Vassalo from Laboratoire de Chimie de l'Environnement Aix-Marseille University for salinity measurements. Thanks also to Cristèle Chevalier and Vincent Rossi from the Mediterranean Institute of Oceanography (MIO) for their helpful advice on backward trajectory computations. We thank the Associate Editor Miriam Diamond and three anonymous reviewers for valuable comments and suggestions. Thanks to IRD for financial and logistical support and for the funding of A.O.'s postdoctoral fellowship. Thanks to the Ministere de l'Ecologie et du Développement Durable for financial support. The project leading to this publication has received funding from European FEDER Fund under project 1166-39417. The project has also received funding from the JPI Oceans PLASTOX project and the Agence de l'Eau Rhône Méditerranée Corse Blue-POLUT and CAREMED projects.

\section{REFERENCES}

(1) Sousa, J. C. G.; Ribeiro, A. R.; Barbosa, M. O.; Pereira, M. F. R.; Silva, A. M. R. A review on environmental monitoring of water organic pollutants identified by EU guidelines. J. Hazard. Mater. 2018, $344,146-162$.

(2) Geyer, R.; Jambeck, J. R.; Law, K. L. Production, use, and fate of all plastics ever made. Science Advances 2017, 3, No. e1700782.

(3) van der Veen, I.; de Boer, J. Phosphorus flame retardants: Properties, production, environmental occurrence, toxicity and analysis. Chemosphere 2012, 88, 1119-1153.

(4) Marklund, A.; Andersson, B.; Haglund, P. Organophosphorus flame retardants and plasticizers in air from various indoor environments. J. Environ. Monit. 2005, 7, 814-819.

(5) Wei, G.-L.; Li, D.-Q.; Zhuo, M.-N.; Liao, Y.-S.; Xie, Z.-Y.; Guo, T.-L.; Li, J.-J.; Zhang, S.-Y.; Liang, Z.-Q. Organophosphorus flame 
retardants and plasticizers: Sources, occurrence, toxicity and human exposure. Environ. Pollut. 2015, 196, 29-46.

(6) Greaves, A. K.; Letcher, R. J. A Review of Organophosphate Esters in the Environment from Biological Effects to Distribution and Fate. Bull. Environ. Contam. Toxicol. 2017, 98, 2-7.

(7) Zha, D.; Li, Y.; Yang, C.; Yao, C. Assessment of organophosphate flame retardants in surface water and sediment from a freshwater environment (Yangtze River, China). Environ. Monit. Assess. 2018, 190, 222.

(8) Hu, M.; Li, J.; Zhang, B.; Cui, Q.; Wei, S.; Yu, H. Regional distribution of halogenated organophosphate flame retardants in seawater samples from three coastal cities in China. Mar. Pollut. Bull. 2014, 86, 569-574.

(9) Lai, S.; Xie, Z.; Song, T.; Tang, J.; Zhang, Y.; Mi, W.; Peng, J.; Zhao, Y.; Zou, S.; Ebinghaus, R. Occurrence and dry deposition of organophosphate esters in atmospheric particles over the northern South China Sea. Chemosphere 2015, 127, 195-200.

(10) Zhong, M.; Wu, H.; Mi, W.; Li, F.; Ji, C.; Ebinghaus, R.; Tang, J.; Xie, Z. Occurrences and distribution characteristics of organophosphate ester flame retardants and plasticizers in the sediments of the Bohai and Yellow Seas, China. Sci. Total Environ. 2018, 615, 1305-1311.

(11) Martínez-Carballo, E.; González-Barreiro, C.; Sitka, A.; Scharf, S.; Gans, O. Determination of selected organophosphate esters in the aquatic environment of Austria. Sci. Total Environ. 2007, 388, 290299.

(12) Cristale, J.; Vázquez, A. G.; Barata, C.; Lacorte, S. Priority and emerging flame retardants in rivers: Occurrence in water and sediment, Daphnia magna toxicity and risk assessment. Environ. Int. 2013, 59, 232-243.

(13) Castro-Jiménez, J.; Berrojalbiz, N.; Pizarro, M.; Dachs, J. Organophosphate ester (OPE) flame retardants and plasticizers in the open Mediterranean and Black Seas atmosphere. Environ. Sci. Technol. 2014, 48, 3203-3209.

(14) Peverly, A. A.; O’Sullivan, C.; Liu, L.-Y.; Venier, M.; Martinez, A.; Hornbuckle, K. C.; Hites, R. A. Chicago's Sanitary and Ship Canal sediment: Polycyclic aromatic hydrocarbons, polychlorinated biphenyls, brominated flame retardants, and organophosphate esters. Chemosphere 2015, 134, 380-386.

(15) Cao, D.; Guo, J.; Wang, Y.; Li, Z.; Liang, K.; Corcoran, M. B.; Hosseini, S.; Bonina, S. M. C.; Rockne, K. J.; Sturchio, N. C.; Giesy, J. P.; Liu, J.; Li, A.; Jiang, G. Organophosphate esters in sediment of the Great Lakes. Environ. Sci. Technol. 2017, 51, 1441-1449.

(16) Guo, J.; Venier, M.; Salamova, A.; Hites, R. A. Bioaccumulation of dechloranes, organophosphate esters, and other flame retardants in Great Lakes fish. Sci. Total Environ. 2017, 583, 1-9.

(17) Danzl, E.; Sei, K.; Soda, S.; Ike, M.; Fujita, M. Biodegradation of bisphenol $\mathrm{A}$, bisphenol $\mathrm{F}$ and bisphenol $\mathrm{S}$ in seawater. Int. J. Environ. Res. Public Health 2009, 6 (4), 1472-1484.

(18) Björnsdotter, M. K.; Jonker, W.; Legradi, J.; Kool, J.; Ballesteros-Gómez, A. Bisphenol A alternatives in thermal paper from the Netherlands, Spain, Sweden and Norway. Screening and potential toxicity. Sci. Total Environ. 2017, 601-602, 210-221.

(19) Pojana, G.; Gomiero, A.; Jonkers, N.; Marcomini, A. Natural and synthetic endocrine disrupting compounds (EDCs) in water, sediment and biota of a coastal lagoon. Environ. Int. 2007, 33, 929936.

(20) Xie, H.; Chen, Q.; Chen, J.; Chen, C.-E. L.; Du, J. Investigation and application of diffusive gradients in thin-films technique for measuring endocrine disrupting chemicals in seawaters. Chemosphere 2018, 200, 351-357.

(21) Fu, P.; Kawamura, K. Ubiquity of bisphenol $\mathrm{A}$ in the atmosphere. Environ. Pollut. 2010, 158, 3138-3143.

(22) Ahrens, L.; Xie, Z.; Ebinghaus, R. Distribution of perfluoroalkyl compounds in seawater from Northern Europe, Atlantic Ocean, and Southern Ocean. Chemosphere 2010, 78, 1011-1016.

(23) Brumovský, M.; Karásková, V.; Borghini, M.; Nizzetto, L. Perand polyfluoroalkyl substances in the Western Mediterranean Sea waters. Chemosphere 2016, 159, 308-316.
(24) Stockholm Convention, Reference: C.N.524.2009.TREATIES4 (Depositary Notification), 2009. http://chm.pops.int/ (accessed June 15, 2019).

(25) Yeung, L. W. Y.; Dassuncao, C.; Mabury, S.; Sunderland, E. M.; Zhang, X.; Lohmann, R. Vertical profiles, sources, and transport of PFASs in the Arctic Ocean. Environ. Sci. Technol. 2017, 51, 67356744.

(26) González-Gaya, B.; Dachs, J.; Roscales, J. L.; Caballero, G.; Jiménez, B. Perfluoroalkylated substances in the global tropical and subtropical surface oceans. Environ. Sci. Technol. 2014, 48, 1307613084.

(27) Cai, M.; Zhao, Z.; Yang, H.; Yin, Z.; Hong, Q.; Sturm, R.; Ebinghaus, R.; Ahrens, L.; Cai, M.; He, J.; Xie, Z. Spatial distribution of per- and polyfluoroalkyl compounds in coastal waters from the East to South China Sea. Environ. Pollut. 2012, 161, 162-169.

(28) Zhou, Y.; Wang, T.; Li, Q.; Wang, P.; Li, L.; Chen, S.; Zhang, Y.; Khan, K.; Meng, J. Spatial and vertical variations of perfluoroalkyl acids (PFAAs) in the Bohai and Yellow Seas: Bridging the gap between riverine sources and marine sinks. Environ. Pollut. 2018, 238, $111-120$.

(29) Fauvelle, V.; Castro-Jimenez, J.; Schmidt, N.; Carlez, B.; Panagiotopoulos, C.; Sempere, R. One-single extraction procedure for the simultaneous determination of a wide range of polar and nonpolar organic contaminants in marine surface water. Front. Mar. Sci. 2018, 5, 295.

(30) Lellouche, J.-M.; Le Galloudec, O.; Drévillon, M.; Régnier, C.; Greiner, E.; Garric, G.; Ferry, N.; Desportes, C.; Testut, C.-E.; Bricaud, C.; Bourdallé-Badie, R.; Tranchant, B.; Benkiran, M.; Drillet, Y.; Daudin, A.; De Nicola, C. Evaluation of global monitoring and forecasting systems at Mercator Océan. Ocean Sci. 2013, 9, 57.

(31) Madec, G.; and the NEMO team. NEMO ocean engine. Note du Pôle de modélisation; Institut Pierre-Simon Laplace (IPSL): France, 2008; vol. 27, pp 1288-1619 (https://www.nemo-ocean.eu/wpcontent/uploads/NEMO_book.pdf).

(32) Lett, C.; Verley, P.; Mullon, C.; Parada, C.; Brochier, T.; Penven, P.; Blanke, B. A Lagrangian tool for modelling ichthyoplankton dynamics. Environ. Model. Softw. 2008, 23 (9), 1210-1214.

(33) Sühring, R.; Diamond, M. L.; Scheringer, M.; Wong, F.; Pućko, M.; Stern, G.; Burt, A.; Hung, H.; Fellin, P.; Li, H.; Jantunen, L. M. Organophosphate Esters in Canadian Arctic Air: Occurrence, Levels and Trends. Environ. Sci. Technol. 2016, 50, 7409-7415.

(34) Korosov, A.; Counillon, F.; Johannessen, J. A. Monitoring the spreading of the Amazon freshwater plume by MODIS, SMOS, Aquarius, and TOPAZ. J. Geophys. Res. Oceans 2015, 120, 268-283.

(35) McDonough, C. A.; De Silva, A. O.; Sun, C.; Cabrerizo, A.; Adelman, D.; Soltwedel, T.; Bauerfeind, E.; Muir, D. C. G.; Lohmann, R. Dissolved Organophosphate Esters and Polybrominated Diphenyl Ethers in Remote Marine Environments: Arctic Surface Water Distributions and Net Transport through Fram Strait. Environ. Sci. Technol. 2018, 52, 6208-6216.

(36) Wang, X.; He, Y.; Lin, L.; Zeng, F.; Luan, T. Application of fully automatic hollow fiber liquid phase microextraction to assess the distribution of organophosphate esters in the Pearl River Estuaries. Sci. Total Environ. 2014, 470-471, 263-269.

(37) Wang, R.; Tang, J.; Xie, Z.; Mi, W.; Chen, Y.; Wolschke, H.; Tian, C.; Pan, X.; Luo, Y.; Ebinghaus, R. Occurrence and spatial distribution of organophosphate ester flame retardants and plasticizers in 40 rivers draining into the Bohai Sea, north China. Environ. Pollut. 2015, 198, 172-178.

(38) Wolschke, H.; Sühring, R.; Xie, Z.; Ebinghaus, R. Organophosphorus flame retardants and plasticizers in the aquatic environment: A case study of the Elbe River, Germany. Environ. Pollut. 2015, 206, 488-493.

(39) Truong, J. W.; Diamond, M. L.; Helm, P. A.; Jantunen, L. M. Isomers of tris(chloropropyl) phosphate (TCPP) in technical mixtures and environmental samples. Anal. Bioanal. Chem. 2017, 409, 6989-6997. 
(40) Pivnenko, K.; Laner, D.; Astrup, T. F. Dynamics of bisphenol A (BPA) and bisphenol S (BPS) in the European paper cycle: Need for concern? Resour. Conserv. Recycl. 2018, 133, 278-287.

(41) Klecka, G. M.; Gonsior, S. J.; West, R. J.; Goodwin, P. A.; Markham, D. A. Biodegradation of bisphenol A in aquatic environments: River die-away. Environ. Toxicol. Chem. 2001, 20 (12), 2725-2735

(42) Zhao, Z.; Xie, Z.; Tang, J.; Sturm, R.; Yingjun, C.; Zhang, G.; Ebinghaus, R. Seasonal variations and spatial distributions of perfluoroalkyl substances in the rivers Elbe and lower Weser and the North Sea. Chemosphere 2015, 129, 118-125.

(43) Lu, Z.; Song, L.; Zhao, Z.; Ma, Y.; Wang, J.; Yang, H.; Ma, H.; Cai, M.; Codling, G.; Ebinghaus, R.; Xie, Z.; Giesy, J. P. Occurrence and trends in concentrations of perfluoroalkyl substances (PFASs) in surface waters of eastern China. Chemosphere 2015, 119, 820-827.

(44) Takemine, S.; Matsumura, C.; Yamamoto, K.; Suzuki, M.; Tsurukawa, M.; Imaishi, H.; Nakano, T.; Kondo, A. Discharge of perfluorinated compounds from rivers and their influence on the coastal seas of Hyogo prefecture, Japan. Environ. Pollut. 2014, 184, $397-404$.

(45) Sühring, R.; Phillips, C.; Gioia, R.; Rowles, R.; Abdoellakhan, I. Perfluorinated compounds in offshore fire-fighting foams - a source for marine contamination? Organohalogen Compd. 2017, 79, 667669.

(46) Rosell-Melé, A.; Moraleda-Cibrián, N.; Cartró-Sabaté, M.; Colomer-Ventura, F.; Mayor, P.; Orta-Martínez, M. Oil pollution in soils and sediments from the Northern Peruvian Amazon. Sci. Total Environ. 2018, 610-611, 1010-1019.

(47) Moquet, J.-S.; Maurice, L.; Crave, A.; Viers, J.; Arevalo, N.; Lagane, C.; Lavado-Casimiro, W.; Guyot, J.-L. $\mathrm{Cl}$ and $\mathrm{Na}$ Fluxes in an Andean Foreland Basin of the Peruvian Amazon: An Anthropogenic Impact Evidence. Aquat. Geochem. 2014, 20, 613-637.

(48) Finer, M.; Jenkins, C. N.; Pimm, S. L.; Keane, B.; Ross, C. Oil and Gas Projects in the Western Amazon: Threats to Wilderness, Biodiversity, and Indigenous Peoples. PLoS One 2008, 3, No. e2932. (49) Thomas, K. V.; da Silva, F. M. A.; Langford, K. H.; de Souza, A. D. L.; Nizzeto, L.; Waichman, A. V. Screening for selected human pharmaceuticals and cocaine in the urban streams of Manaus, Amazonas, Brazil. J. Am. Water Resour. Assoc. 2014, 50 (2), 302-308. (50) Foltz, G. R.; Schmid, C.; Lumpkin, R. Transport of surface freshwater from the equatorial to the subtropical North Atlantic Ocean. J. Phys. Oceanogr. 2015, 45 (4), 1086-1102.

(51) Coles, V. J.; Brooks, M. T.; Hopkins, J.; Stukel, M. R.; Yager, P. L.; Hood, R. R. The pathways and properties of the Amazon River Plume in the tropical North Atlantic Ocean. J. Geophys. Res. Oceans. 2013, 118, 6894-6913.

(52) Castro-Jiménez, J.; Casal, P.; González Gaya, B.; Pizarro, M.; Dachs, J. Organophosphate ester flame retardants and plasticizers in the global oceanic atmosphere. Environ. Sci. Technol. 2016, 50, 12831-12839.

(53) Stein, A. F.; Draxler, R. R.; Rolph, G. D.; Stunder, B. J. B.; Cohen, M. D.; Ngan, F. NOAA's HYSPLIT atmospheric transport and dispersion modeling system. Bull. Am. Meteorol. Soc. 2015, 96, 2059-2077.

(54) Rolph, G.; Stein, A.; Stunder, B. Real-time Environmental Applications and Display sYstem: READY. Environ. Model Softw. 2017, 95, 210-228.

(55) Medeiros, P. M.; Seidel, M.; Ward, N. D.; Carpenter, E. J.; Gomes, H. R.; Niggemann, J.; Krusche, A. V.; Richey, J. E.; Yager, P. L.; Dittmar, T. Fate of the Amazon River dissolved organic matter in the tropical Atlantic Ocean. Global Biogeochem. Cy. 2015, 29, 677690.

(56) Moreira-Turcq, P.; Seyler, P.; Guyot, J. L.; Etcheber, H. Exportation of organic carbon from the Amazon River and its main tributaries. Hydrol. Processes 2003, 17, 1329-1344.

(57) Lebreton, L. C. M.; van der Zwet, J.; Damsteeg, J.-W.; Slat, B.; Andrady, A.; Reisser, J. River plastic emissions to the world's oceans. Nat. Commun. 2017, 8, 15611.
(58) Li, F.; Wang, L.; Ji, C.; Wu, H.; Zhao, J.; Tang, J. Toxicological effects of tris(2-chloropropyl) phosphate in human hepatic cells. Chemosphere 2017, 187, 88-96.

(59) Wu, H.; Zhong, M.; Lu, Z.; Shan, X.; Li, F.; Ji, C.; Cong, M. Biological effects of tris (1-chloro-2-propyl) phosphate (TCPP) on immunity in mussel Mytilus galloprovincialis. Environ. Toxicol. Pharmacol. 2018, 61, 102-106.

(60) Nohara, D.; Kitoh, A.; Hosaka, M.; Oki, T. Impact of climate change on river discharge projected by multimodel ensemble. J. Hydrometeorol. 2006, 7, 1076-1089.

(61) Jambeck, J. R.; Geyer, R.; Wilcox, C.; Siegler, T. R.; Perryman, M.; Andrady, A.; Narayan, R.; Law, K. L. Plastic waste inputs from land into the ocean. Science 2015, 347, 768-771. 